\title{
ANOTHER TRADITIONAL ARCHITECTURE IN CANADA AND THE USA: EXPLORING SOME UNIQUE CONSTRUCTIVE TECHNIQUES
}

\author{
V. La Spina ${ }^{1, *}$ \\ ${ }^{1}$ Departamento de Arquitectura y Tecnología de la Edificación, Universidad Politécnica de Cartagena - vincenzina.laspina@upct.es
}

Commission II - WG II/8

KEY WORDS: Stovewood Construction, Sod Houses, Cobblestone Structures, Vernacular architecture, Canada, USA

\begin{abstract}
:
Generally, in the traditional architecture of Canada and the United States, wood has been used as the main and almost exclusive material for the construction of the buildings of early settlers as it was abundant in the area. Thus, $\log$ cabins or wooden frame houses and cottages have become the chief representatives of traditional Canadian and North American architecture. However, wood was expensive or not always at hand in some parts of both countries, so that other materials such as earth, stone, and lime or gypsum were used by the new settlers to build the first constructions. Consequently, different constructive techniques associated with these materials are found in their traditional architecture, some even imported from Europe, with specific links to the individual places of origin of those who built the buildings. This paper aims to provide an initial overview and classification of the use of other materials and other constructive techniques which are also characteristic of a part of traditional architecture common to both Canada and the North of the United States: It also offers an exploration of different specific individual examples including stovewood constructions, sod houses (soddies), and cobblestone structures.
\end{abstract}

\section{INTRODUCTION}

It is practically impossible not to associate traditional architecture in Canada and the United States with wooden constructions, that is, log cabins or sawn wooden frame houses (Figures 1 and 2). However, timber has not always been readily available in the vast North American expanse due to the lack of forest areas in wide parts of both countries, such as the Great Prairies, or it has been a material requiring greater expense and more skilled labour, unattainable for many first settlers.

According to Morrison (1987) the first colonists in the 17 th century built four types of constructions or temporary shelters: dugouts, cabins, wigwams, and cottages. The first were simple holes dug in the ground and roofed over by poles and bark; sometimes they were only half-excavated with an upper wall built of sods (Figure 3). Morrison's 17th-century interpretation of a cabin depicted a flimsier structure than that observed today. These cabins were made of vertical stakes driven into the ground, with wattles (willow or hazel withes) woven between them and daubed with clay with a roof of poles and turf or thatch. From Quebec to the Carolines, wigwams were oblong round-roof structures which consisted of a framework of slender poles, with butt ends stuck into the ground, and tops that were bent over and lashed together to form a semi-cylindrical roof, a framework covered by woven mats or pressed bark or skins (Figure 4). Finally, cottages were built with frames of hewn planks or squared timbers, covered by wide boards laid flush or smaller lapped clapboards. In some cases it was possible to observe wattle-and-daub walls, like those in England, although these were most likely used as filling. Therefore, these constructions were not made exclusively of wood and some of them, such as the wigwam, took their inspiration from Native American Indian constructions (Figure 5).

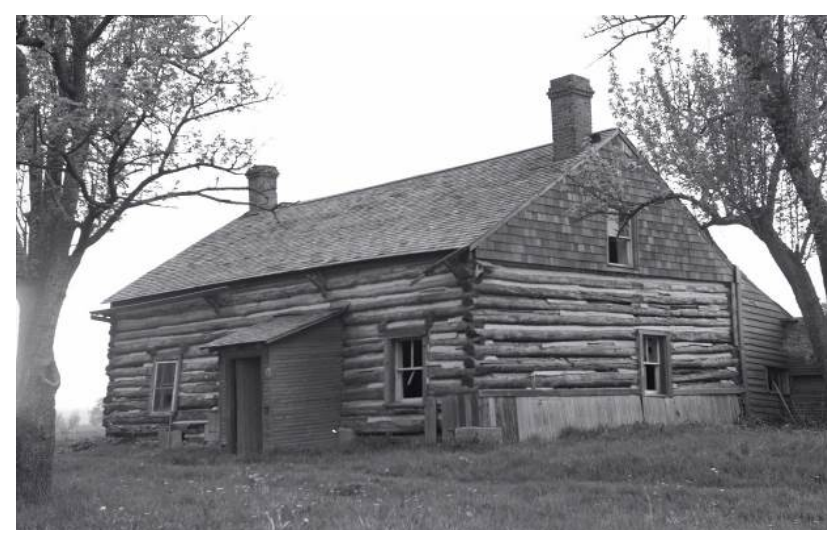

Figure 1. Log cabin in Victoria Park Ave., at end of Ellesmere Rd, Toronto, 1956 (Source: Courtesy of Toronto Public Library).

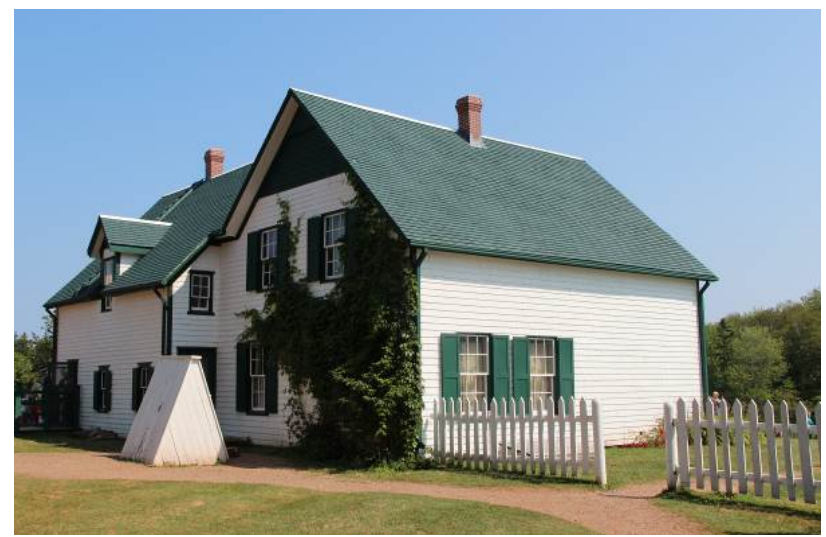

Figure 2. Traditional Wood construction on Prince Edward Island, Canada (Source: author).

* Corresponding author 
Later, as the occupied territory in North America increased, when the new settlers needed to build longer lasting and more resistant buildings the means and resources available conditioned the use of materials and the different constructive techniques executed. However, in many cases the geographical origin of settlers and their traditional constructive techniques, together with those learnt on the American continent, also had significant impact. The variety of constructive solutions in the early buildings was also observed at later stages and has been partly examined in the bibliography.

This article therefore aims to showcase other traditional techniques, relating not only to wood, but also to materials such as earth and stone. This study offers an exploration of other traditional constructive techniques, aiming to promote a more thorough examination of its importance, historical development and future perspective and specific technical details. In addition, it aims to establish as much of a correlation between the origin of the colonists who arrived in each individual area and European and local constructive traditions. However, given the size and diversity of both Canada and the United States, this research has focused mostly on the area of the Great Lakes and the Great Prairies, shared by both countries, in the Canadian states of Ontario, Alberta, Saskatchewan, and Manitoba, and in the American states of Maine, Vermont, New York, Pennsylvania, Ohio, Michigan, Indiana, Illinois, Wisconsin, Minnesota, North Dakota, and Montana (Figure 6).

The methodology mostly consists on the analysis of different bibliographical and archival sources; texts, historic publications, and university articles or studies, from the mid-19th century to present-day, and consulted mostly at the Université de Montreal. In addition, personal visits were carried out whenever possible to traditional constructions in order to access sources of information directly. It should also be borne in mind that several of the buildings used as examples of the constructive techniques examined in this study sadly no longer exist, and all that is left of them is bibliographical or photographic evidence or later reconstructions in natural parks.

A series of traditional constructive techniques using timber, earth and stone are therefore described below, in an attempt to provide information on execution, origin and main characteristics or specific details. These techniques are described in order in various sections.

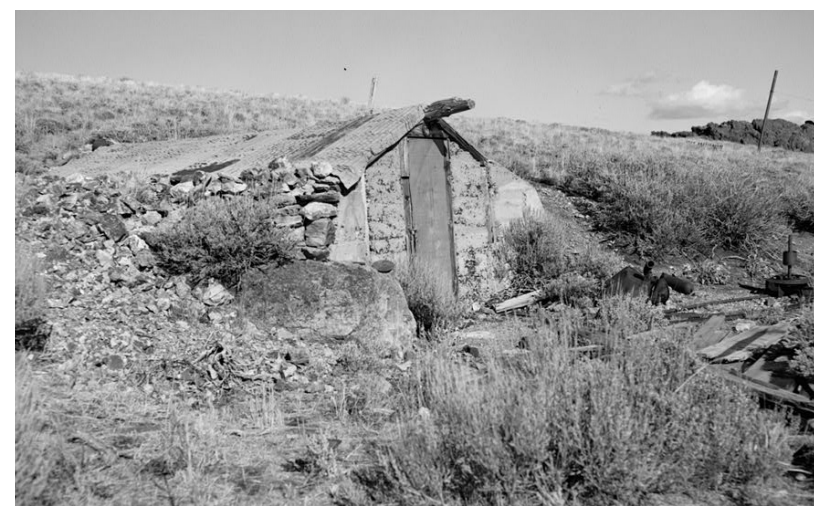

Figure 3. Bell Family Residence, Dugout, East slope of Buckskin Mountain, Paradise Valley, Humboldt County, NV (Source: Historic American Engineering Record - Library of Congress).

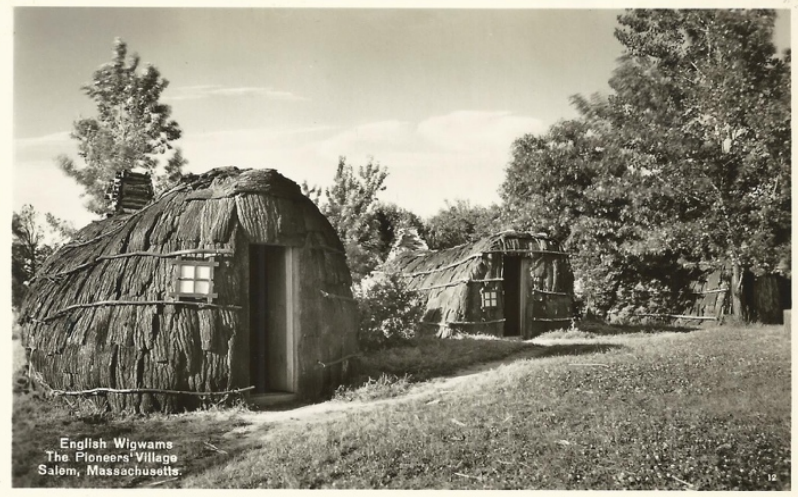

Figure 4. English wigwams at the Pioneers' Village (Source: Salem Public Library, accessed April 6, 2020,

https://digitalheritage.noblenet.org/salem/items/show/46).

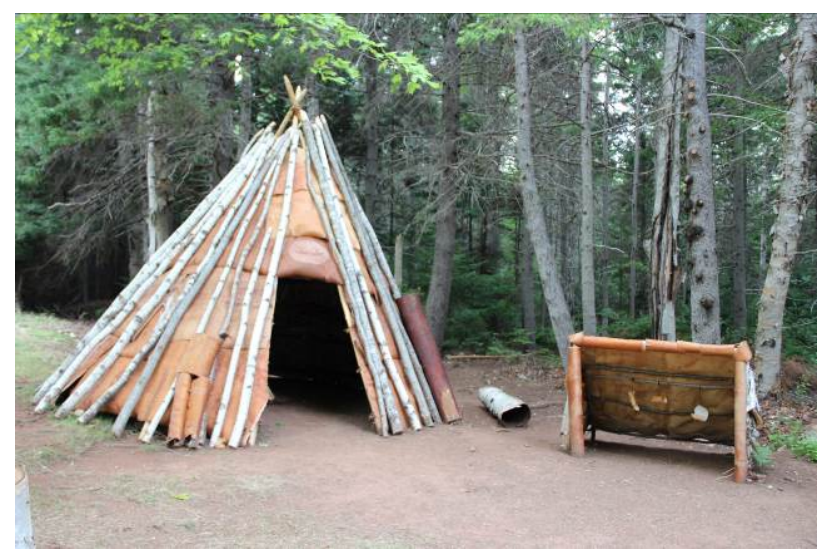

Figure 5. Traditional Mi'kmaq construction in Skmaqn-Port-laJoye-Fort Amherst National Historic Site, near Charlottetown,

PEI, Canada. Mi'kmaq are a First Nations people of the Northeastern Woodlands (Source: author).

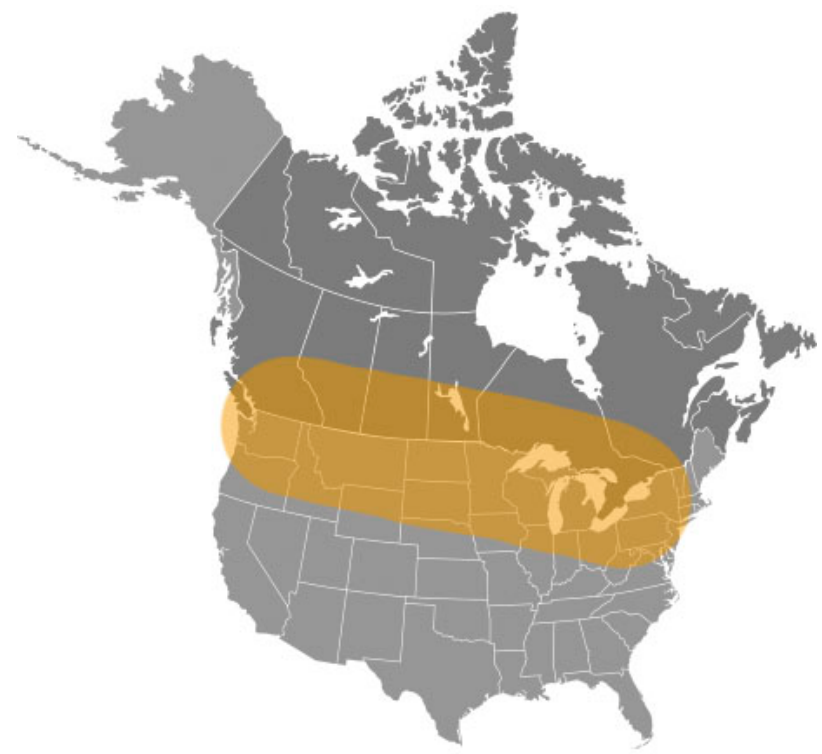

Figure 6. Area studied (Source: author). 


\section{OTHER TRADITIONAL CONSTRUCTIVE TECHNIQUES IN NORTH AMERICA}

Historically, earth, stone and wood have been and continue to be the materials most widely used in the construction of buildings all over the world. This has led to the existence of numerous traditional constructive techniques closely linked to them and known in varying degrees. In this respect, North America is no exception and not all traditional architecture is exclusively timber (Mileto, Vegas, 2015 and 2018). Therefore, below follows an initial examination of the most unique and, to a great extent, least known, constructive techniques using timber, earth, and stone, and mainly found in Canada and the United States, where both countries share the geographical landmarks of the Great Lakes and Great Prairies.

\subsection{Stovewood construction: another way to use wood}

The constructions erected following the constructive technique of stovewood, also known as log butt, cordwood, woodblock and stackwall, are mostly found in Wisconsin, where according to Tishler (1982) over 70 structures were documented in the 1980s. One of the most notable is one of the largest commercial constructions known using this technique, the Mecikalski Stovewood General Store, built in 1895 (and restored in 1985 by the Kohler Foundation) in Pelican Lake, Oneida County, Wisconsin. It measures 24 by 33 feet (approximately 7.30 by 10 $\mathrm{m})$. However, there is also evidence of several constructions built with this technique in Iowa, Minnesota, Michigan, Illinois, and as far west as Montana, as well as in parts of the St. Lawrence Valley in Canada (Ontario and Quebec).

Stovewood constructions differ greatly from traditional North American $\log$ constructions or balloon-frames, as they are made from logs of uniform lengths cut into sections, set in lime mortar, and stacked perpendicular to the length of the wall. They got their name from their similarity to logs stacked as fuel, as the ends of the logs are left exposed (Figure 7). Cedarwood, with characteristic high insulation and resistance to decomposition, was normally used, as well as oak, as can be seen from the early examples of construction in southern Wisconsin and northeast Iowa in the mid-19th century (Tishler, 1982). Furthermore, according to the studies by Tishler, three basic types of stovewood construction can be distinguished. The first, found mostly in granaries, sheds, and chicken coops in the county of Door (in Mideast Wisconsin), has a characteristic structure framed with heavy timbers with wall panels filled with a nogging of stovewood, resulting in a type of half-timber construction. The stovewood here has no structural function and the length of the logs is conditioned by the measurements of the timber frame. However, in the second type the walls are loadbearing and therefore solid. These solid stovewood walls are built without an encasing structural framework and different constructive details were added on the corners. As Figure 8 shows, solutions on the corner could feature a wood section used like stone ashlar (A), a squared piece of wood placed vertically along the height of the construction (B), or alternating layers of pieces of wood (C). Although found mainly in Wisconsin, this typology is also the most common in Canada. Finally, the third option, which is more recent than the previous ones, is a balloon-frame system of rough sawn lumber in which relatively short sections of stovewood are stacked between the studding in the walls. This type of structure was mainly used for dwellings and sided with clapboard, as the stovewood was used primarily for insulation.
The main advantages of this constructive solution are technological, financial and aesthetic. Firstly, stovewood constructions do not require long pieces of straight, high-quality timber necessary for other wood buildings. Wood could even be reused from abandoned cedar rail fences or the remains of structures destroyed by fire. Secondly, stovewood structures were simple 'do-it-yourself' solutions which did not require skilled labour and, in isolated areas, one man working alone could erect the walls without help. Thirdly, other advantages of this constructive technique were energy efficiency, especially when air cells were left inside the lime mortar. It should also be noted that this was an inexpensive form of construction both due to the low cost of materials and the unskilled labour widely used in the 1930s. According to Tishler's study, in 1937 the construction of a stovewood garage cost $\$ 5,000$, while a similar building using conventional cinder block constructions cost approximately $\$ 14,000$. Finally, the aesthetic merit of the façades is undeniable, as in keeping with Roy (2016), the solution combines the warmth of wood and the pleasing relief and visual interest of stone masonry.

The origin of this constructive technique is still widely discussed. Tishler (1982) highlights its possible connection to the Scandinavian immigrants to North America, as evidence of this sort of construction has been found in Norway and Sweden. However, other studies suggest that French Canadian loggers pioneered this form of construction, passing it on to the German and Polish immigrants who built most of Wisconsin's seventy or so documented stovewood buildings between 1880 and 1910 (Wisconsin Historical Society, 2020). Another theory is that the few stovewood structures in Europe may have been built by immigrants returning from North America, something which would make it an original constructive tradition from the United States which later spread to other parts of the world.

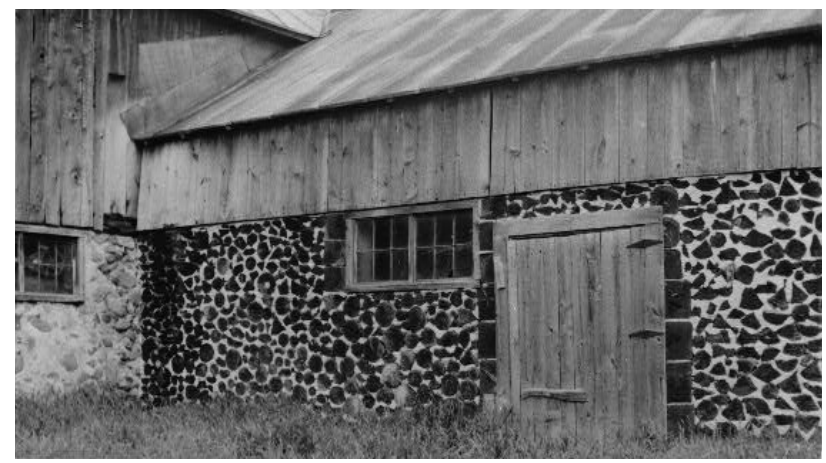

Figure 7. Wood Block Masonry Barn, No. 1, Lena, Oconto County, WI (Source: Library of Congress).

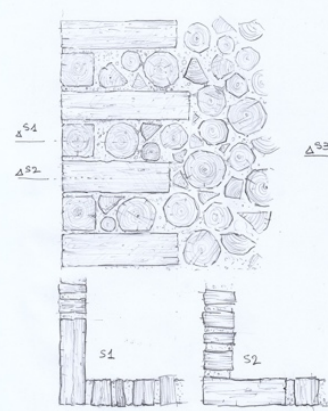

A

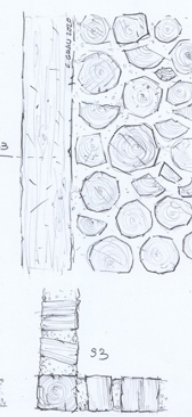

B

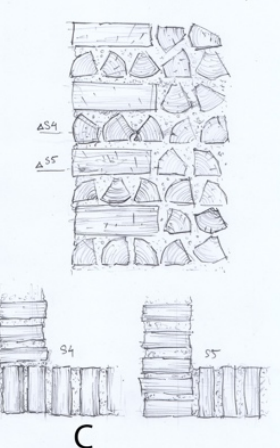

C
Figure 8. Drawing by the author of the different corners in loadbearing stovewood walls (Drawings: C.J. Grau, 2020). 


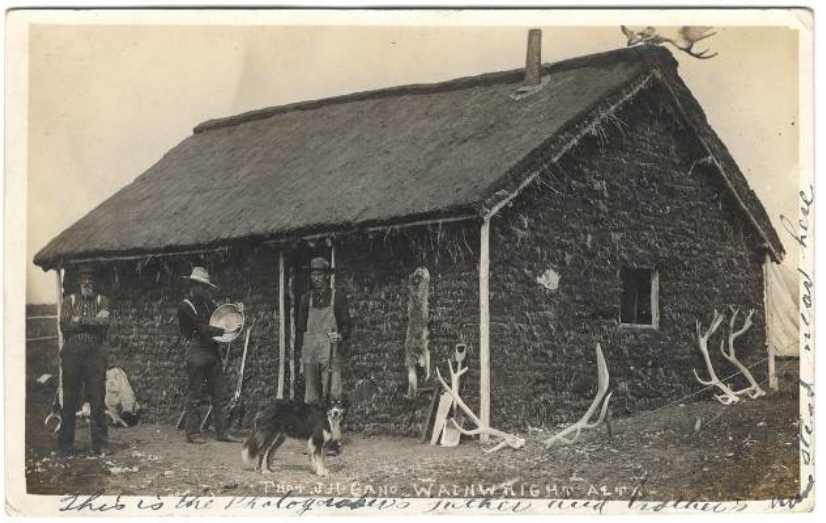

Figure 9. Sod house in Alberta in 1911 "That J. H. GANO Wainwright Alberta" (Source: jasonwoodhead23).

\subsection{Some earthen constructive techniques: sod, adobe and rammed earth}

The use of earth in North America is generally associated with arid climate zones such as the south-western United States or Mexico, where Hispano-American construction traditions are found. However, different publications and studies, as well as buildings still preserved, highlight how different traditional earthen techniques have also been used in humid areas of Canada and the north of the US, as well in their huge prairies, where they are more closely related to the techniques of the immigrants from northern and eastern Europe, as highlighted in research by Mileto \& Vegas, Panneton, Ritchie, Rempel, Pieper, etc. Below is a detailed study of some of the most important traditional constructive techniques including sod houses, adobe / mud bricks / unburnt bricks and rammed earth.

2.2.1 Sod house: Sod houses were very common during the growing settlements in the large North American plains due to their low cost and as the scarcity of wood in the area meant that colonists had to explore alternative construction methods. In Canada, the western expansion towards the great prairies (Alberta, Saskatchewan and Manitoba) was greatly boosted by immigration from Eastern Europe (Figure 9). This technique disappeared following the development of the railway network, which made it possible to transport sawn wood at an affordable cost. As a result, it was mostly used between the 1850 s and the 1910s (Noble, 1981).

The technique consisted in extracting grass in areas where it was tougher and more fibrous with heavy roots, ploughing it and cutting it into strips 2 to 3 feet long $(60-90 \mathrm{~cm})$ and 16 or 18 inches wide $(40-45 \mathrm{~cm})$. The sods were then placed with the grass facing down, one directly on top of the other, with the joints overlapping as if they were bricks or stones. The blocks of grass were superimposed and held together by their long fibrous roots. When applicable, doors and windows were built and the sods piled up around them. It was also common to place telegraph poles in the ground to support the walls, while log plates finished off the walls. The roofs were built using light elm boards or posts, which also tended to be covered with grass, hay or straw depending on the materials available. The interior walls were then rendered in a layer of mud or lime, or heavy white wallpaper (Ritchie, 1967) or fabric was added to the walls.

The buildings built using this technique could vary greatly, as observed in the photographs of the publication by Butcher (1904) and general observations from Mileto \& Vegas (2018).
They ranged from simple temporary shelters to two-storey buildings. A unique example of this is Addison Sod House in Kindersley, Saskatchewan, built between 1909 and 1911, which is still standing and was designated a National Historic Site by the Historic Sites and Monuments Board in 2004. It is unique for its construction with a wooden roof and sloping walls, with a variation in thickness from 4 feet in the lower section to 3 in the upper one (approximately $120 \times 90 \mathrm{~cm}$ ). It was covered, first with vines, then with cedar shingles which in time were covered with asphalt and vinyl siding (Panneton, 2017). Furthermore, in Canada, the Dominion Land Act of 1872 stipulated that the average house needed to have a surface of at least 432 sq. feet (around $40 \mathrm{~m}^{2}$ ), guaranteeing minimum measurements.

Without doubt, the main features of this constructive solution are affordability and simple technique. However, these were greatly dependent on whether the end result of the building was complex or if the owner was simply adding comforts such as windows, hinges or boards for a door (Panneton, 2017). Equally, they all shared the same thermal characteristics, and were cool in summer and warm in winter. In contrast, they also presented some unique complications. This was especially the case with simple temporary shelters, where earth would often fall off the roof or where insects and mouse nests which happened to be in the sod strips frequently ended up unscathed in the walls of a house. Furthermore, leaks were not uncommon.

Finally, it should be noted that archaeological evidence points to the fact that this constructive technique also has its architectural roots in American indigenous and Nordic practices (Panneton, 2017). Indigenous peoples in southern British Columbia, the Prairies, the Arctic, and Labrador commonly built sod housing. An example of this is the archaeological site of L'Anse aux Meadows, at the north end of Newfoundland (Canada), where several sod houses found are thought to have been built by Norse settlers around the year 1000 (11th century).

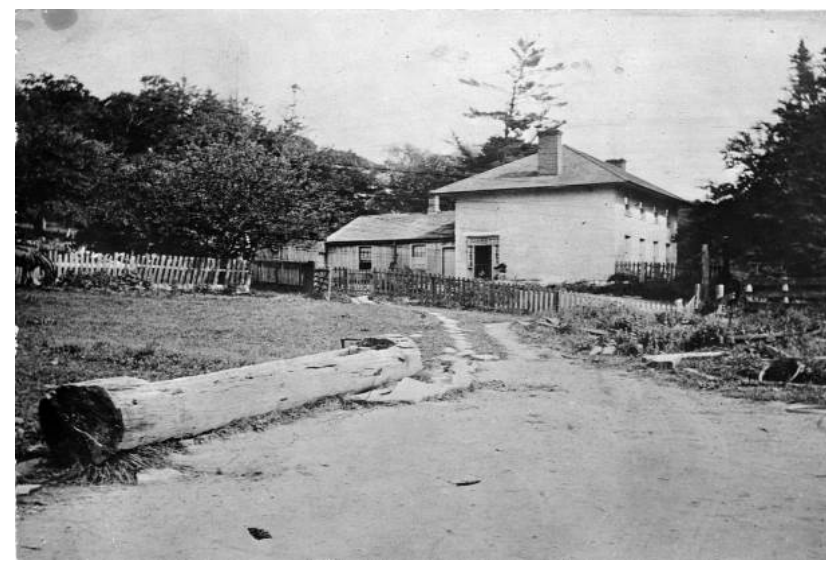

Figure 10: Helliwell, Thomas, house, Pottery Rd., south side, east of Don R., Toronto, Ont., Unknown, Picture, 187- (Source: Courtesy of Toronto Public Library).

2.2.2 Adobe / mud brick / unburnt bricks: Adobe is the most widely used earthen technique throughout the United States (Mileto, Vegas, 2018) and Canada (Unzueta, 2015). This is partly due to the dissemination of different publications describing the technique and advantages of its use for construction. 
In fact, thanks to all these publications we know that as early as 1836 buildings were built using unburnt bricks near Toronto, Canada and that in 1842 this technique was used to build the new church of Hurontario. Also since 1842, The British American Cultivator (1842, 1843a, 1843b), an agricultural magazine from Toronto, provided information on the construction and features of mud brick buildings (Pieper 1999), as did the publication Scientific American (1847a and 1847b), and the book The house. A pocket manual of Rural Architecture written by D. H. Jacques in 1859. At the same time, in the United States, several reports by U.S. Patents Commissioner Henry Leavitt Ellsworth, point out that mud brick buildings also being built in Washington, DC and Grand Prairie, Indiana from 1842, and state that this technique was also used in the prairie settlements with no wood. In turn, the technique spread throughout several counties in New York State, as well as Pennsylvania, Michigan and Nebraska, and the counties of York and Simcoe, both in Ontario, Canada. A noteworthy example in New York State is the city of Geneva, where numerous unburnt brick buildings date from the mid19th century, and at least 14 of the 22 are registered in Ontario County according to Pieper (1999). At the same time, the highest concentrations of this type of building are found in Toronto and its surroundings. These include examples like Helliwell House (Figure 10), still in good condition with adobe walls protected by wide eaves and thick exterior rendering, as well as other buildings such as churches, schools, and hotels (Rempel, 1980).

Unburnt bricks were used mostly because they were inexpensive (both in terms of construction and repair), and because their production required only the right clay and unskilled labour, both generally available (Rempel, 1980). According to the publication The British American Cultivator (1843a) "....also cheaper than frame, and are destined to take the place of the log shanty, as well as the more expensive wooden walls". In fact, a number of houses had been built by contract, at a rate of $£ 1$ per hundred brick, (including building) for an area of 75 feet (around $7 \mathrm{~m}^{2}$ ) of wall so that the walls of a house, 30 feet square (approximately $3 \mathrm{~m}^{2}$ ) and 15 feet high $(4.5 \mathrm{~m})$, would only cost $£ 35$ (The British American Cultivator, 1842). Moreover, according to Rempel (1980) and The British American Cultivator (1843a), in the Township of York (Ontario), Mr Beason used 2248 unburnt bricks to build a house and he charged $£ 22 / 10 / 0$ laid.

The production method was very simple. All that was needed was a ditch full of pure clay (preferably blue) and abundant water to saturate it completely for at least 24 hours. After this it was compacted or tempered by oxen while adding four bales of short straw for every 100 bricks. The bricks were then moulded and left to dry in a sheltered location. The cheapest size was considered to be a foot long, 6 inches wide, and 4 inches thick ( $30.48 \mathrm{~cm}$ long, $15.24 \mathrm{~cm}$ wide and $10.16 \mathrm{~cm}$ thick). A weak lime and sand mortar was used to build walls a foot thick, but when lime was not available the mortar used was made up of 3 parts clay, 1 part sand, and 2 parts wood ash. It was also considered that "Houses properly constructed of this material are warmer, more durable..." and even that "Clay or unburnt brick houses are much more wholesome for either man or beast, than either burnt brick or stone, in consequence of their having less affinity to moisture" (The British American Cultivator, 1843a).

However, it was also clear that it was necessary to protect the outside of these buildings from rain, damp, and wind. This is why the construction of a stone base was recommended, as well as verandas or balconies around the entire building, or 3 inches $(7.62 \mathrm{~cm})$ overhangs in the eaves. In addition, in October a good rendering was to be applied to walls under 15 feet high (approximately $4.5 \mathrm{~m}$ ) because it would fall off more easily if applied higher up. There were even specific 'recipes' for renderings to protect from the damp, for example: "an equal proportion of pure clay, sand, ashes and lime, thoroughly incorporated together, and mixed with a portion of fresh bullocks' blood, equal to one half of each of the above ingredients. The blood should be well stirred to prevent it from coagulating" according to Rempel (1980) or "a thin coat of mastic which is prepared by mixing very coarse sharp sand, or sifted road drift, with dry White Lead and Litharge, beaten up with Linseed oil, and rendered sufficiently soft to work well with a towel" according to the publication Scientific American, (1847b). The use of bond timber was also recommended as its purpose was two-fold: firstly to fix accessories such as verandas, bases, and door and window sills to walls using boards placed a few inches from the outside of the wall; and secondly, to act as plates for beams in two-storey buildings, when the use of wood at least 4 inches $(10 \mathrm{~cm})$ thick was advised.

Nevertheless, despite all these recommendations and advice the technique was gradually abandoned from the $1850 \mathrm{~s}$, mainly due to issues arising in buildings from the detachment of renderings and the increased popularity of other cheaper materials such as brick and sawn timber.

2.2.3 Rammed earth / pisé: The constructive technique of rammed earth was promoted in North America through early 19th-century translations and adaptations of texts by French agriculturalist and architect François Cointeraux. Another translation worth mentioning is that by Holland, as well as Stephen Johnson's plagiarised reworking. These texts encouraged several experiments with rammed earth in the midAtlantic and the southeast United States which were chronicled in agricultural journals in the first four decades of the 19thcentury (Pieper, 1999). However, according to Condit (1982) as far back as the early years of colonialism, rammed earth walls and walls of loose rubble piled in circular or elliptical plans were the most primitive forms of proto-masonry construction. There is little evidence of this kind of building and it was apparently confined to Virginia and Massachusetts Bay (Condit 1982).

It thus appears that this technique was not only used in the Southwest or due to a scarcity of other materials, as was the case on the treeless prairies. For instance, in the north of New York State, there are reports of agricultural constructions on a rammed earth base with a structure of wooden boards above (Mileto, Vegas, 2018). Moreover, according to Betts \& Miller, although there were few examples in the US in 1926, two of these were in Washington DC, one built in 1773 and the other more recent.

In the same way, in Canada an important example of this technique is found in St Thomas' Church in Shanty Bay, Ontario built in 1838, which according to its commemorative plaque is "... one of the few surviving structures in Ontario built of "rammed earth". This method of construction utilized wet clay mixed with chopped straw, compacted into forms and covered, when dry, with plaster or siding for protection against weather" (Figure 11). This is therefore a clear example of a building erected with a simple rammed earth variant, but with the peculiarity of incorporating chopped straw in the mix (Mileto, Vegas, 2018). However, different publications 
contradict this information. For example, Unzueta (2015) does not take into account that the mix was compacted and therefore considers it a shuttered earth building, while Rempel (1980) views it as an example of 'mud construction', and Gowans (1958 and 1966), states that "The walls were built of mud and straw, trampled into brick by oxen; this is a variant of the 'wattle-and daub'.

There is often confusion when describing or defining the specific earthen constructive technique used in most of the buildings from this period. This is mostly due to the fact that walls cannot be examined without their rendering or to the simplified interpretation which considers all earthen constructions to be 'Mud Houses', even many years later. A clear example of this is the unusual 'Mud House', built by Blair Burrow, author of the book Building with mud, rammed earth or pisé de terre (194?) in King City, Ontario in 1937 (Admin, 2008). This building was in fact made of rammed earth, a century after St Thomas' Church, when the use of this technique was revived partly following World War I and II, thanks to new publications and as a result of the Great Depression which affected North America and the limited resources available (Gramlich, 2013).

In fact, from 1919 on the continuing international crisis led to numerous books and articles promoting the use of rammed earth as a building solution, emphasizing the availability of the material and the simplicity of construction. These books included Cottage Building in Cob, Pisé, Chalk \& Clay, written by Clough Williams-Ellis in 1919; Rammed earth walls for buildings and Lower Cost Buildings: A Handbook on Building Walls with Rammed Earth published by the U.S. Department of Agriculture in 1924 and 1926 respectively; and Rammed Earth Walls for Farm Buildings edited by the Agricultural Experiment Station, South Dakota State College of Agriculture and Mechanic Arts, in 1933.

Generally, rammed earth construction was considered the best solution for rural structures where building materials could not be easily obtained. According to the literature, the technique did not require skilled artisans and could be followed by anyone with no previous experience and capable of carefully following instructions. Moreover, "...the result of his own labour produces cheap, attractive, and durable structures, the walls of which provide dryness and insulation against heat and cold." (Betts, Miller, 1926)

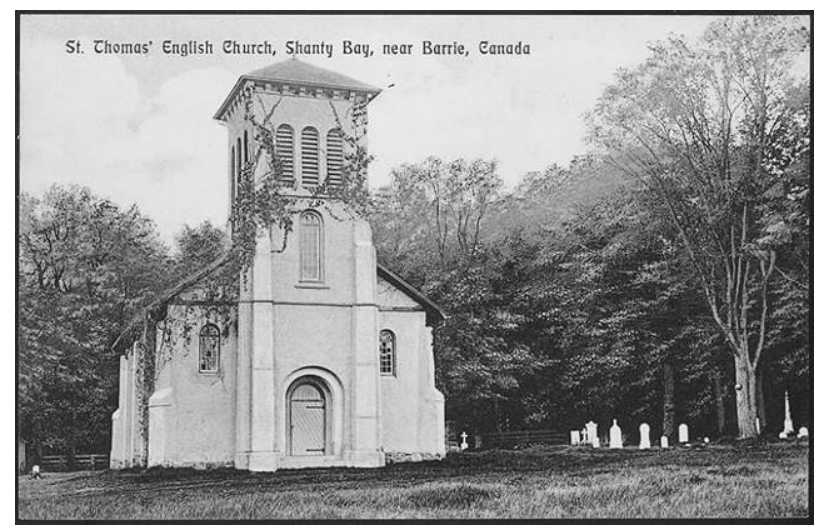

Figure 11. St. Thomas' English Church, Shanty Bay, near Barrie, Canada, N.W.E. King, Picture, 1910

(Source: Courtesy of Toronto Public Library).

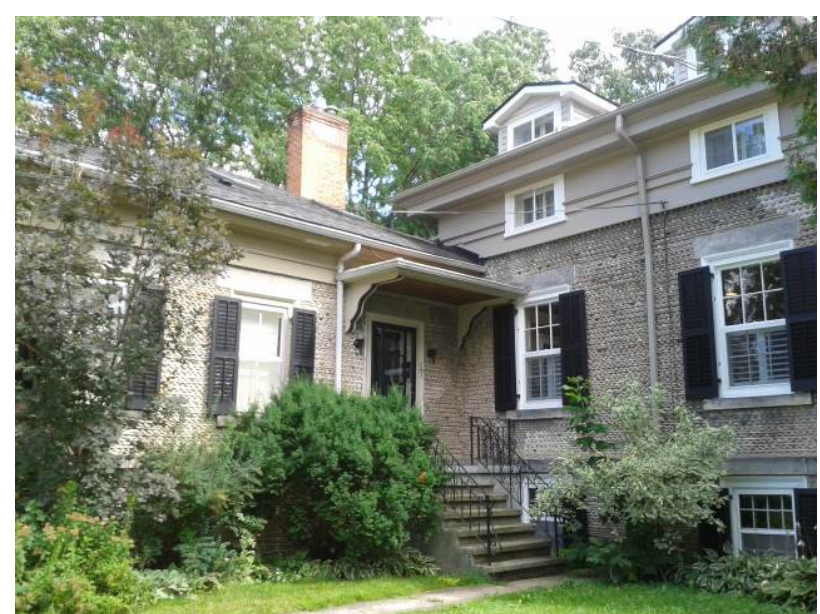

Figure 12. Cobblestone construction, Hamilton Place in Paris, Ontario, Canada (Source: author).

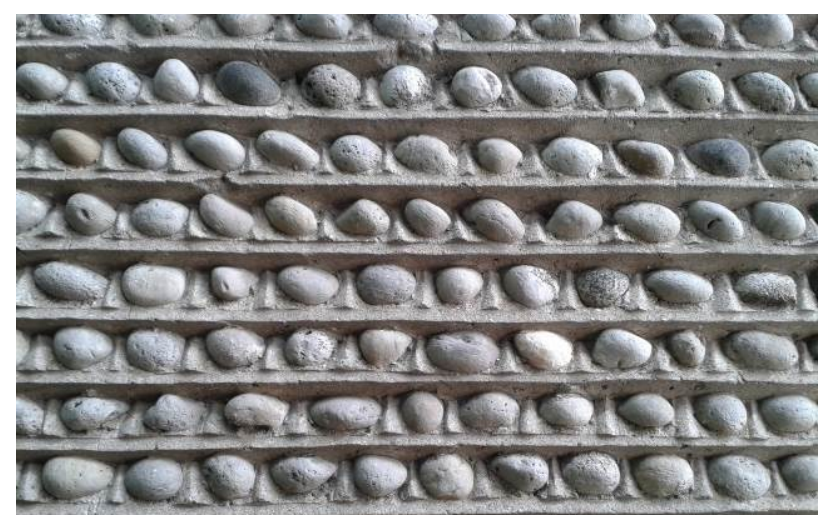

Figure 13. Cobblestone detail in Hamilton Place in Paris, Ontario, Canada (Source: author).

\subsection{Cobblestone construction: a variant of masonry}

The cobblestone technique is characterised by the use of pebbles incorporated into a thick layer of lime mortar, with a major axis at right angles to the wall and only a small portion projecting beyond the outer surface. Cobblestones tend to be the size of a fist, can be held with one hand, and are extracted near rivers or crop fields.

According to Moynihan (2007), cobblestone structures were built between 1825 and 1860 south of lake Ontario and around the Finger Lakes of central New York (buildings inventoried in his study: New York 900, Paris-Ontario 12; Brattleboro Vermont 2; Michigan 10 and Wisconsin/Illinois 22). In Canada, the technique reached Paris (Brant, Ontario) in 1838 thanks to Levi Bougton, a builder from Normandale, NY. It then spread to the surrounding areas as well as to Baldwin on route 48 (Rempel, 1980) and to Belleville, east of Toronto (Cruickshank, 2000). Hamilton Place (Figures 12 and 13) and George Brown House in Paris, built in 1844 and 1850 respectively, are especially noteworthy for their excellent state of conservation and the refined constructive techniques. In 1860, most of the cobblestone buildings were in Wayne County, between Rochester and Syracuse, and thus, no more than 70 miles from Rochester, New York. However, in later decades the technique spread to the west of Wisconsin, then back to the east of Vermont and to the north in the south of Canada. 


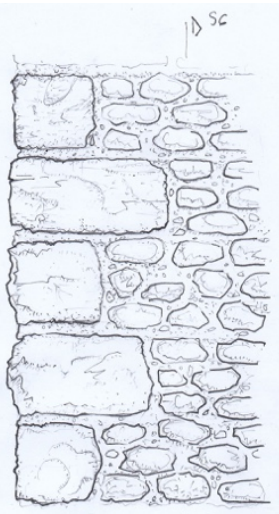

A

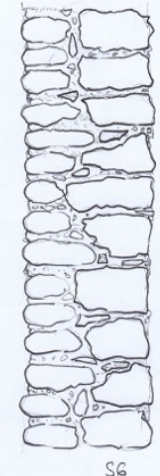

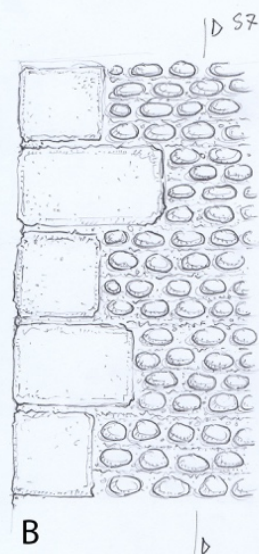
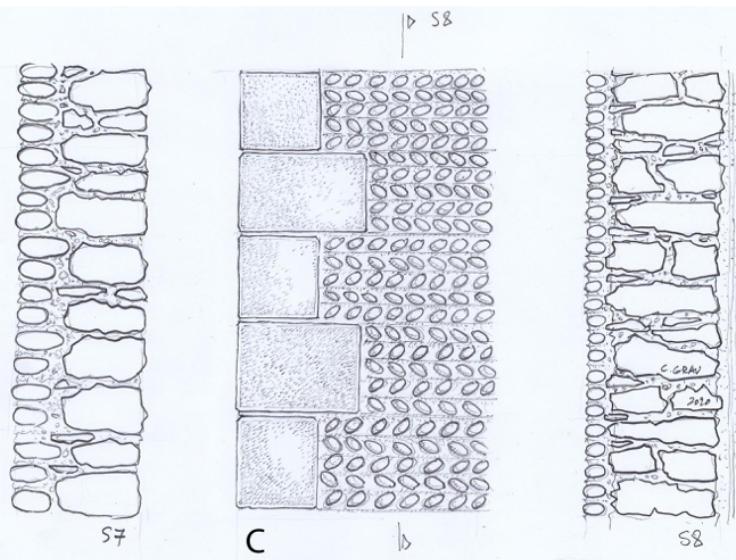

Figure 14. Drawing by the author of the main phases of cobblestone construction:

A) early period, B) middle period and C) late period

(Source: Moynihan, 2007. Drawings: C.J. Grau, 2020).

In addition, its appearance is considered to be closely linked to the construction of the Erie Canal, and stone extracted during perforations was used to build abutments, retaining walls, and other such structures along the canal (Rempel, 1980). It is also thought that the technique was introduced to New York by English settlers from East Anglia or from Suffolk and Cambridgeshire according to Ritchie (1967). Both this theory and the myth of unemployed Irish labourers or masons building the cobblestone structures after the completion of the Erie Canal are contested by Moynihan (2007). Nevertheless, it cannot be denied that 18th-century English flint and cobblestone buildings are the most promising examples of a plausible precedent to American cobblestone construction are (Moynihan, 2007).

Three main phases are described in the bibliography on cobblestone construction: early, middle and late and these should be considered technical rather than temporary variants. As Figure 14 shows, the first category includes the examples which featured a solid wall of interlaced, irregular field cobbles collected from local farms where three distinct layers of cobbles can be found working outwards, with larger stones found in the inner two thirds of the wall. In the second category, the middle phase, the constructions have a fieldstone wall with a waterwashed cobblestone veneer of regular courses. The refined exterior face integrated long cobbles which held the veneer and rubble wall together. Meanwhile, in the final phase and category, a fieldstone rubble wall was built and a cobblestone veneer was then laid separately. The cobblestones used in this typology were smaller and the designs more refined. The use of smaller cobblestones gradually changed to the point that they became a merely decorative layer with no structural function as a wall. Therefore, some examples are highly irregular due to inexperienced workmen, while others displayed the finest cobblestone work, with a striped effect produced by laying alternate rows of stones in contrasting colours.

One of the main features of this constructive technique is the large number of people required for its execution. Up to 14,000 cobblestones could be needed for the construction of a building; these were collected by children, future owners, or - in the case of churches - members of the congregation. These then had to be sorted and classified with the aid of special boards with different-sized holes, as well as being separated by colour, a task usually delegated to women. Finally, the builders or owners placed them in layers of thick lime mortar, and only about four even courses could be completed in a day to allow the mortar to set (Chapple, 2007). Not only is the final result really beautiful, but also highly resistant to the elements. However, cobblestone constructions were not as inexpensive as other constructive techniques and were not always applied to all 4 façades of a building. For this reason, the back façade often featured a different technique, for example uncut field stone laid up in rough courses with abundant mortar (Ritchie 1967). Moreover, this technique ceased to be used in the construction of buildings in the 1860s, when brick became more affordable and available, while the considerable increase in the price of labour also meant cobblestone construction was no longer cost-effective (Chapple, 2007).

\section{CONCLUSIONS}

This article showcases just a few of the more unique or lesserknown traditional constructive techniques common to historic buildings in Canada and the United States. These show that timber was not the only material used in North America, thus dispelling myths such as that of the log cabin and the use of earth exclusively in North America's arid climate regions, such as the southwestern United States.

These techniques generally display little specialization, and at times involve future owners. But above all, they are inexpensive. Nevertheless they have been successfully adapted to the environment and the resources available, and clearly display efficiency and sustainability. They also highlight the resourcefulness of the settlers, who often reinterpreted European and native traditional techniques. In addition, although some of the buildings erected using these techniques were supposed to be simple provisional solutions until other more permanent ones could be built, those still standing are further proof that they are worthy of consideration and recognition.

However, this study is simply an initial examination of the topic, which deserves further in-depth research, in specific areas of both countries, also examining other traditional materials such as lime and gypsum. For example, the research provided evidence of the use of gypsum construction blocks, both in inner and outer walls, in many houses in southern Ontario (Ritchie, 1967). Moreover, future studies should also establish more connections with constructive techniques found in Europe, highlighting the similarities or differences introduced to adapt to the existing resources and climate conditions. And, finally, 
another point of interest could be the analysis of how these traditional techniques are now being rediscovered and used in new buildings. One example of this is Rob Roy and his wife, who have been constructing stovewood buildings since 1975 (Roy 2016) or new rammed earth buildings such as that found in Castleton, Ontario (Cautius, 2014).

\section{ACKNOWLEDGEMENTS}

This work was carried out as part of a research stay at Faculté de l'Aménagement at Université de Montréal in 2017.

This work is part of the research project "RISK-Terra. Earthen architecture in the Iberian Peninsula: study of natural, social and anthropic risks and strategies to improve resilience", funded by the Spanish Ministry of Science, Innovation and Universities (Ref.:RTI2018-095302-B-I00; main researchers: Camilla Mileto and Fernando Vegas López-Manzanares).

\section{REFERENCES}

Admin, 2008: Ontario Rammed Earth House. Earth Architecture. Architecture, Design, and Culture using of mud, clay, soil, dirt \& dust, https://eartharchitecture.org/?p=433, Accessed 20 January 2020 .

Betts M. C., Miller T.A.H., 1926: Rammed Earth walls for buildings. In U.S. Department of Agriculture, Farmers' Bulletin, $n^{\circ} 1500$, Washington, D.C.

Butcher, S. D., 1904: Sod houses or the development of the great American plains. A pictorial history of the men and means that have conquered this wonderful country. Western Plains Publishing Co., Chicago.

Cautius C.E., 2014: Rammed Earth: Adaptions to urban Toronto. Thesis of Master of Architecture, University of Waterloo.

Chapple, N., 2007: Cobblestone Capital. The Beaver, 87(4), 5455 .

Condit, C. W., 1982: American building. Materials and techniques from the beginning of the Colonial settlements to the present. The University Chicago Press, Chicago and London.

Gowans, A., 1958: Looking at Architecture in Canada. Oxford University Press, Toronto.

Gowans, A., 1966: Building Canada. An architectural History of Canadian life. Oxford University Press, Toronto.

Gramlich, A. N., 2013: A concise history of the use of the rammed earth building technique including information on methods of preservation, repair, and maintenance. Thesis of Master, Historic Preservation and the Graduate School of the University of Oregon.

Jacques, D. H., 1859: The house. A pocket manual of Rural Architecture. Fowler and Wells, New York.

Mileto, C., Vegas, F., 2015: Conservation of earthen architecture in the United States of America: Some case studies. In Earthen Architecture: Past, Present and Future, Taylor \& Francis Group, London.
Mileto, C., Vegas, F., 2018: Earthen heritage in the USA: Approximation to constructive techniques. In Vernacular and Earthen Architecture: Conservation and Sustainability, Taylor \& Francis Group, London.

Moynihan, R., 2007: The Mystery of cobblestone construction. Thesis of Master, Faculty of the Graduate School of the State, University of New York at Buffalo.

Morrison, H. 1987: Early American Architecture. From the first Colonial Settlements to the National Period. Dover Publications, Inc., New York.

Noble A. G., 1981: Sod Houses and similar structures: a brief evaluation of the literature. Pioneer America, 13 (2) (September), 61-66.

Panneton, D., 2017: Sod Houses. The Canadian Encyclopedia, Historica Canada. https://thecanadianencyclopedia.ca/en/article/sod-houses. Accessed 20 January 2020.

Pieper, R., 1990: Earthen Architecture of New York State; Adobe Construction in a non-arid climate. $6^{\text {th }}$ International Conference on the Conservation of Earthen Architecture. The Getty Conservation Institute, Los Angles, 117-121.

Pieper, R., 1999: Earthen Architecture in the Northern United States. European Traditions in Earthen Construction. Halifax: Cultural Resource Management, 22(6), 30-33.

Rempel, J. I., 1980: Building with wood and other aspects of nineteenth-century building in central Canada. University of Toronto Press, Toronto.

Ritchie, T., 1967: Canada Builds, 1867-1967. University of Toronto Press, Toronto.

Roy, R., 2016: Cordwood building: a comprehensive guide of the state of the art. New Society Publishers, Gabriola Island, Canada.

Scientific American, 1847a: Houses of unburnt bricks, 2(44), 368.

Scientific American, 1847b: Cheap houses, 2(44), 346.

Tishler, W. H., 1982: Stovewood Construction in the Upper Midwest and Canada: A Regional vernacular Architectural Tradition. Perspective in Vernacular Architecture, 1, 125-136.

The British American Cultivator, 1842: Cheap houses, 1(1), 1.

The British American Cultivator, 1843a: Unburnt brick houses, 2(2), 21 .

The British American Cultivator, 1843b: Unburnt brick houses, 2(3), 40 .

Unzueta, L., 2015: Fabric remnants of a forgotten past: $19^{\text {th }}$ Century earthen Architecture of South-Central Ontario. Earth USA 2015, 52-57.

Wisconsin Historical Society, 2020: Mecikalski General Store, Saloon, and Boarding house, Schoepke, Oneida, Wisconsin, 21112. Wisconsin Architecture and History Inventory. https://www.wisconsinhistory.org/Records/Property/HI21112 Accessed 20 January 2020. 